Int. J. Dev. Biol. 62: 257-264 (2018)

https://doi.org/10.1387/ijdb.170323mm

\title{
Illuminating the chicken model through genetic modification
}

\author{
MEGAN G. DAVEY* , ADAM BALIC, JOE RAINGER, HELEN M. SANG and MICHAEL J. MCGREW \\ Roslin Institute Chicken Embryology (RICE), The Roslin Institute and Royal Dick School of Veterinary Studies, \\ University of Edinburgh, Midlothian, UK
}

\begin{abstract}
After decades of research investment, techniques for the robust and efficient modification of the chicken genome are now with us. The biology of the chicken has provided many challenges, as have the methods by which transgenes can be readily, stably and functionally integrated into the genome. Now that these obstacles have been surmounted and the chicken has been 'updated' to a cutting-edge modern model organism, a future as a central and versatile model in developmental biology beckons. In this review, we describe recent advances in genetic modification of the chicken and some of the many transgenic models developed for the elucidation of the mechanisms of embryogenesis.
\end{abstract}

KEY WORDS: chicken, embryology, transgenic, genetic modification, gene editing, fluorescent proteins

\section{Introduction}

Early methods of genetic modification, while too inefficient for routine application have paved the way for current, more successful technologies (Sang, 2004). The first genetically-modified chickens were generated by transduction of early chick embryos in freshly laid eggs using vectors derived from avian retroviruses (Bosselman et al., 1989) but the frequency of transgenic offspring produced was low and there was evidence that transgenes introduced in these vectors were subject to epigenetic silencing. Direct injection of plasmid DNA into zygotes recovered from the oviducts of laying hens was used successfully to generate transgenic birds but this approach was expensive in use of animals and inefficient (Love et al., 1994). Considerable advances were made in developing the chicken equivalent of embryonic stem cells which could be genetically modified in vitro and used to form chimeric birds when introduced into embryos in newly-laid eggs, but these cells never contributed to the germline, probably because of the biology of germ cell lineage in birds, which are thought to be determined prior to lay (Tsunekawa et al., 2000).

These early attempt formed the basis of the techniques which are not used successfully to genetically modify chickens; lentiviral vectors have replaced retroviral vectors and recent developments using cultured primordial germ cells (PGCs) have provided opportunities for targeted, defined modifications of the chicken genome. These most recent transgenic technologies have been used to exploit the protein production capacity of laying hens in the development of GM chickens as bioreactors (Lillico et al., 2005) and raise the possibility that the future genetic improvements of chickens for food production may be achieved through transgenic technologies. In developmental biology, modern transgenesis has allowed the utilisation of an increasing range of fluorescent proteins expressed ubiquitously in both chickens and quails as well as under specific enhancers. This has allowed direct in vivo analysis, replaced quail donor embryos in transplantation studies and provided alternatives to transplantation experiments.

\section{Methods for production of transgenic chickens}

\section{Lentiviral and transposon vectors for transgene addition}

The early research using retroviral vectors for production of transgenic chickens identified the potential advantages of using an infectious vector that carries its own integrase and can easily be applied to embryos in newly-laid eggs. This formed the basis of a more efficient method that used lentiviral vectors (McGrew et al., 2004). Lentiviral vectors have been developed from members of the lentivirus group of retroviruses e.g. HIV, EIAV, which have the advantage of being able to infect non-dividing cells, with a major driver being to use the vectors for human gene therapy. This method has been used successfully as the basis for the generation of transgenic lines that are discussed below and was in parallel developed for production of transgenic quail (Scott and Lois, 2005). The process results in hatch of founder generation birds $\left(G_{0}\right)$ that are chimeric for the transgene carried by the lentiviral vector (from $5-100 \%$ of hatched birds) (Fig. 1A). DNA extracted

Abbreviations used in this paper: PGC, primordial germ cell.

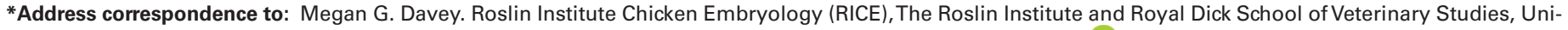
versity of Edinburgh, Easter Bush Campus, Midlothian, EH25 9RG, UK. E-mail: megan.davey@ roslin.ed.ac.uk - iD http://orcid.org/0000-0003-0194-9229
} 
A
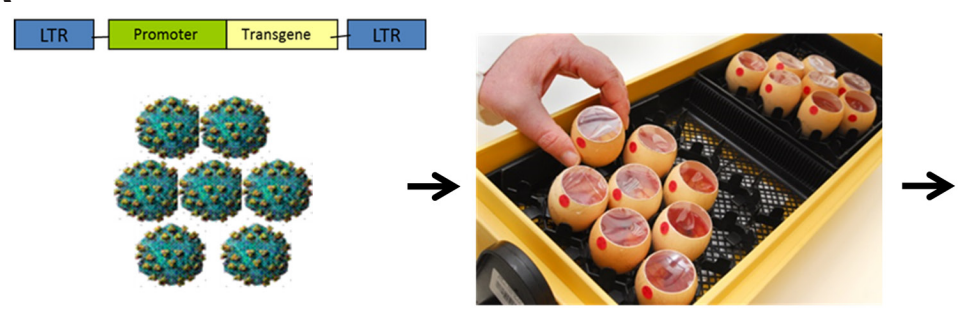

B

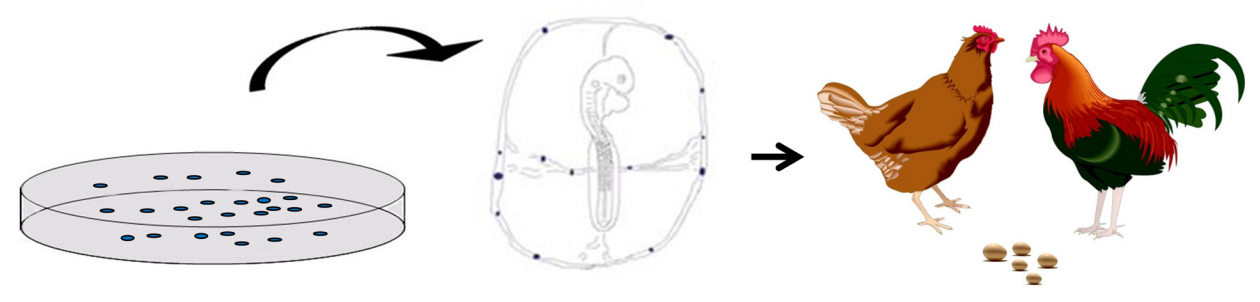

Fig. 1. Transgenesis using lentiviral vectors and targeting primordial germ cells (PGCs) to produce genetic knockouts. (A) A transgene is cloned into the lentiviral vector, packaged and injected into laid chicken eggs. The eggs are incubated until hatch and the resulting birds mated to transmit the transgene to the $G$ generation. (B) PGCs are cultured in vitro and genetically modified and subsequently re-introduced into surrogate host embryos. The embryos are incubated, hatched, raised to sexual maturity and mated to generate $G$, transgenic offspring, for example this TALEN-edited hen containing a targeted knockout of DDX4.

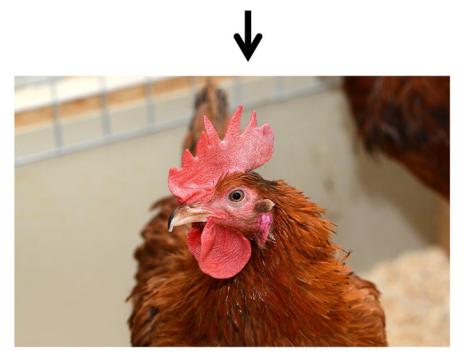

from semen of these $G_{0}$ birds is then screened to identify males that will transmit the integrated vector, which are then bred and fully transgenic chicks identified in the next, $\mathrm{G}_{1}$, generation at levels from $1 \%$ to $>50 \%$. Our published and unpublished results of using this system are that transgenes integrated using lentiviral vectors are stably transmitted and transgene expression is stable for many generations.

There has long been interest in the use of transposon-derived vectors in the chicken system, for example by transfection of blastoderm stage embryos. A relatively recent advance has been the injection of transposon vectors complexed with lipofection reagent into embryos at approximately stage $16 \mathrm{HH}$, when PGCs are migrating via the blood stream to the gonadal primordia (Tyack et al., 2013). The method described by Tyack and colleagues used Lipofectamine 2000 plus a Tol2 transposon vector and demonstrated that stable transfection of PGCs resulted in germline transmission of a transgene in the vector at a level of $\sim 1.5 \%$ of $G_{1}$ chicks, with 2 of 11 cockerels transmitting the vector/ transgene. This approach has the advantage of relative technical simplicity, although the frequency of transgenic bird production is fairly low, and particularly because it can readily be adapted for use in other avian species.

\section{In vitro culture and genome engineering of chicken primor- dial germ cells}

The ultimate objective of genetic modification technologies is to target the cells of the germ cell lineage in order to transmit the genetic modification to the progeny of the modified animal. But how best to target these cells? Blastodermal cells isolated

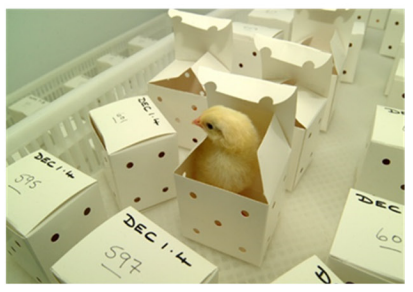

from the laid chicken egg can be transferred to recipient eggs and will contribute to both somatic and germ cell lineages (Petitte et al., 1990). Unfortunately, unlike mouse ES cells chicken blastodermal cells do not contribute the germ cell lineage after propagation for more than six days in vitro (Etches et al., 1996, Pain et al., 1996, van de Lavoir et al., 2006b). The likely reason for this could be that the germ cell lineage in birds is determined by the deposition of maternal factors (RNA, proteins) in the oocyte, which are segregated to a small population of cells in the early embryo (Eyal-Giladi et al., 1981, Nieuwkoop and Sutasurya, 1979, Tsunekawa et al., 2000). This population of cells is called the Primordial Germ Cells (PGCs). Thus while the chicken ES cells did not appear to be the route to targeting of the adult germ cell, the PGCs which differentiate into the gametes of the adult bird provided an alternative target for genetic modification.

Importantly PGCs can be isolated from the embryos and indeed germline transmission and direct targeting of chicken primordial germ cells has been achieved both in vitro and in vivo after short periods of culture at both early and gonadal stages of development (Chang et al., 1995, Kalina et al., 2007, Kim et al., 2010, Vick et al., 1993). A revolutionary breakthrough for the field of avian transgenesis was the ability to culture germline competent chicken PGCs for an extended time. In the seminal work by Van de Lavoir (2006a), chicken PGCs were cultured and genetically modified in vitro using phiC integrase to promote integration of transfected plasmid DNA. When transplanted into host embryos at stage $16 \mathrm{HH}$, the PGCs were able to colonise the developing gonads and form functional gametes which transmitted the genetic modification to the offspring (Fig. 1B) (Choi et al., 2010, Macdonald et al., 2010, van de Lavoir et al., 2006a). Culturing chicken PGCs has been difficult due to the complex culture conditions required for growth, including bovine and chicken serum and feeder cells (Choi et al., 2010, Macdonald et al., 2010, van de Lavoir et al., 2006a). Recently, the cell signalling mechanisms involved in self-renewal of chicken PGCs were determined and a defined serum-free medium for the propagation of chicken PGCs was developed (Whyte et al., 2015). This advance greatly facilitates the opportunities to genetically modify the genome of the chicken via cultured PGCs.

The development of the isolation, culture and transfection techniques in order to modify the PGC as a route to transgenesis, 
is only part of the story. The method of integrating a transgene functionally into the genome of modified PGCs has also been challenging. DNA transposable elements are able to efficiently modify cultured PGCs and generate transgenic offspring (Macdonald et al., 2012, Park and Han, 2012). Importantly, the DNA transposons are not silenced in either the PGCs or the resulting transgenic birds. The arrival of Genome Editors (zinc finger nucleases, TALENs, Crispr/CAS9), however, have been as revolutionary in the development of chicken genetic modification as they have been in other animals. Genome editors are site-specific DNA nucleases which are able to precisely target the vertebrate genome (reviewed in Cong, (2015)). Genomic cleavage results in either non-homology driven end joining (NHEJ), that leads to small deletions/insertions at the target cleavage site, or, in the presence of a DNA template containing a region of homology surrounding the cleavage site in homology directed repair (HDR) that will lead to incorporation of an exogenous DNA sequence (from a few basepairs up to kilobases of sequence) at the target site.

Gene knockout chickens containing small deletions of the genome using Crispr/CAS9 have been produced using both Crispr/ CAS9 and TALEN vectors in PGCs (Oishi et al., 2016, Park et al., 2014). Crispr/CAS9 and TALEN vectors have also been used to increase the efficiency of HDR in cultured PGCs (Dimitrov et al., 2016, Taylor et al., 2017). The world's first knockout chicken containing loss of function of the chicken vasa homologue, DDX4 was produced this year (Fig. 1B), bringing the chicken model inline with the mouse and zebrafish as a model genetic organisms. DDX4 female chickens containing the genetic deletion are sterile due to a loss of germ cells during meiosis and could be used for the generation of future GE chicken. These old and new methods for avian transgenesis are generating novel tools for investigating development, immunology, and fertility and to date a number of different chicken and quail transgenic lines primarily for developmental biology studies (see Table 1).

\section{Applications}

\section{Developmental biology}

Fate mapping the origin of cells and organs during embryonic development has been one of the main strengths of using the chicken embryo to study vertebrate development. Cell labelling techniques used have included marking cells with carbon particles, vital dyes or radioisotopes, or more recently with lipophilic fluorescent dyes such as Dil (DilC18(3)). As well as being often difficult to apply and trace, vital dyes become diluted over time by cell division (Bower et al., 2011). A major advance in the use of the chicken as a model for embryonic fate mapping was developed by with Prof. Nicole Le Douarin who showed that chicken:quail chimeras (transplantation of selected cells/tissues from quail embryos into chicken embryo hosts) forms the basis of a method of permanently marking cells during embryogenesis (Le Douarin and Dieterlen-Lievre, 2013). Le Douarin and colleagues used this method extensively to study the development of the neural crest for example, determining the importance of this embryonic structure and discovering the multiple tissue types it gives rise to during embryogenesis. Chicken:quail chimeras are powerful because they allow the progeny of grafted cells to be followed throughout development but they can only be identified through histological processing, either by staining to show the distinct morphology of the quail nucleolus or by staining with a quail-specific antibody. A disadvantage of this system is that quail grafts cannot be visualised in live tissues but these elegant experiments, undoubtedly laid the ground work for developing transgenic models in mammals, and later on in chicken and quails, for further fate mapping work, involving live imaging.

TABLE 1

\section{TRANSGENIC AVIAN MODELS}

\begin{tabular}{|c|c|c|c|c|}
\hline Name & Transgene & Fluorophore Reporter & Additional notes & Lab/Country/Reference \\
\hline \multicolumn{5}{|l|}{ Chicken } \\
\hline Roslin Green & CAG-eGFP & eGFP & CAGGS promotor, ubiquitous & $\begin{array}{l}\text { Sang/UK } \\
\text { McGrew et al., } 2008 \\
\text { Ros/Spain } \\
\text { Chapman/USA }\end{array}$ \\
\hline Roslin memGFP & CAG-mem eGFP & eGFP & ubiquitous membrane eGFP & Sang/UK \\
\hline Flamingo & CAGtdTomato & tdTomato & ubiquitous & Sang/UK \\
\hline Chameleon & CAGCytbow & eYFP, tdTomato, mCerulean & ubiquitous (Cre-recombinase dependent recombination) & Sang/UK \\
\hline Cre-lox-GFP & CAG LoxP-STOP-LoxP-eGFP & eGFP & ubiquitous (Cre-recombinase dependent recombination) & Sang/UK \\
\hline MacReporter & CSF1R-eGFP/mApple & eGFP, mAPPLE & CSF1R promoter/enhancer, macrophages & $\begin{array}{l}\text { Sang/Hume/UK } \\
\text { Balic et al., } 2014\end{array}$ \\
\hline Hes5-VNP & Hes5-VNP-NLS-PEST & destabilized nuclear Venus & Notch-reporter line & $\begin{array}{l}\text { Baek et al in submission } \\
\text { Sang/UK }\end{array}$ \\
\hline \multicolumn{5}{|l|}{ Quail } \\
\hline GFP & CAGeGFP & eGFP & ubiquitous & Gros/Institute Pasteur \\
\hline tdTomato & CAGdtTomato & tdTomato & ubiquitous & Gros/Institute Pasteur \\
\hline hUbC:memGFP & & eGFP & ubiquitous membrane eGFP & Gros/Institute Pasteur \\
\hline hUbC:H2bGFP & & eGFP & ubiquitous nuclear eGFP & Gros/Institute Pasteur \\
\hline hUbC:mEos2FP & & eGFP-RFP & & Gros/Institute Pasteur \\
\hline $\begin{array}{l}\text { Lifeact-NeonGreen_ires_Myosin- } \\
\text { tdTomato }\end{array}$ & & NeonGreen, tdTomato & & Gros/Institute Pasteur \\
\hline PGK:H2b-mcherry & & mCherry & & $\begin{array}{l}\text { Langford/USA Gros/Institute Pasteur } \\
\text { Huss et al., } 2015\end{array}$ \\
\hline Tie1;H2b-eYFP & & eYFP & Endothelial cell specific & $\begin{array}{l}\text { Langford/USA Gros/Institute Pasteur } \\
\text { Sato et al., } 2010\end{array}$ \\
\hline Synapsin1:eGFP & & eGFP & Neurons & Scott and Lois, 2005 \\
\hline Synapson1:H2B::eGFP & & eGFP & Nuclear localised signal, neurons & Seidl et al., 2012 \\
\hline
\end{tabular}




\section{Ubiquitious labelled transgenic lines}

The mostly highly utilised transgenic line in avian model in embryology is the Roslin Green (Table 1), and these have been expanded from their source at The Roslin Institute to establish flocks in Spain and the USA. These birds were developed through a lentiviral mediated integration of eGFP expressed ubiquitously in embryos under control of the "CAGGS" composite enhancer/ promoter ((McGrew et al., 2008); Fig. 2B). They demonstrated the power of stably labelled chicken embryos by transplantation of cells from the chordoneural hinge $(\mathrm{CNH})$ of GFP embryos to the $\mathrm{CNH}$ of a non-GFP recipient embryo. After letting the embryos develop for 24 hours the CNH GFP cells were then re-isolated and grafted back into younger host embryos. This showed that the $\mathrm{CNH}$ cells were still competent to contribute to neural and non-neural tissue, therefore demonstrating that the $\mathrm{CNH}$ contains a stem-cell population.

While the $\mathrm{CNH}$ is identifiable morphologically, the SHHexpressing cells of the posterior limb bud organiser, the zone of polarising activity (ZPA) is not. To understand how this transient group of cells contributes to the patterning of the limb bud, Towers, Tickle,
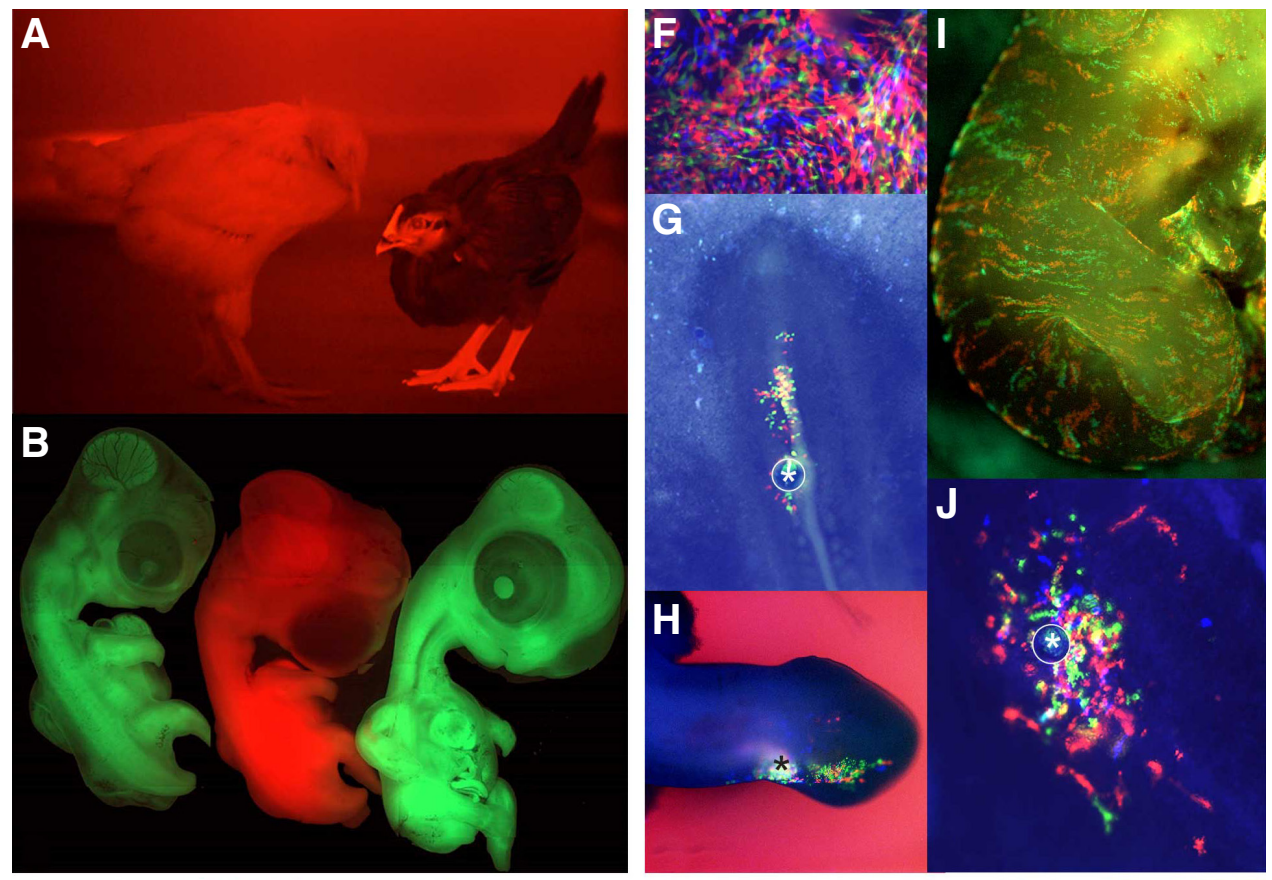

Fig. 2 Fluorescent chicken models for developmental biology. (A) tdTomato fluorescent transgenic (brown hen, right) with wt sibling (white hen left), showing expression of tdTomato fluorescent protein in the skin of the face and legs. The pigment of the feathers prevents observation of the tdTomato fluorescent protein. (B) Roslin Green GFPembryos on either side of a tdTomato transgenic embryo. (C) A classic ZPA organiser graft experiment similar to that undertaken by John Saunders in the wing. A Roslin Green host, in ovo, with a tdTomato posterior polarising region (ZPA;red; arrow) leg graft placed ectopically in the anterior leg bud. When placed in the anterior of the developing leg bud at stage $20 \mathrm{HH}$ (as shown) the graft, which contains $\mathrm{SHH}$ expressing cells, causes the induction and patterning of extra anterior ectopic digits (show in D). (D) Using tdTomato donor polarising region leg bud grafts, it is possible to observe that the tdTomato positive ZPA graft give rise to digit 4 (red asterisk), but not digit 3 (white asterisk), demonstrating that as in the mouse $\mathrm{SHH}$ expressing cells contribute
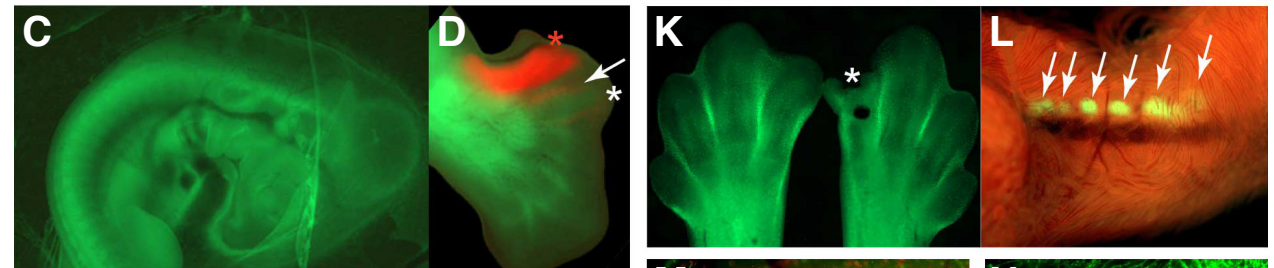
to the autocrine induction and patterning of digit 4 and the paracrine induction and pattering of digit 3. Additionally, it can be observed with tdTomato, that cells migrate from the ZPA graft and contribute to the tissue around digit 3. (E) tdTomato cells derived from a ZPA graft can be visualised after extensive
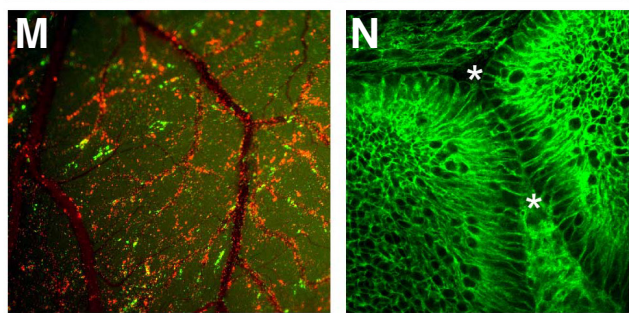
fixation and processing migrating away from the source of the donor tissue, without any additional antibody or detection methods. (F) Fibroblasts, in vitro, derived from a heterozygous CPX transgenic chicken line embryo. TAT-Cre recombinase protein was added to the culture medium, inducing recombination at the Cytbow transgene, allowing expression of eYFP (green), tdTomato (red) or MCFP (blue) and preventing expression of nuclear H2B-eBFP2 (not shown). (G, $\mathbf{H}, \mathbf{I}, \mathbf{J})$ TAT-Cre recombinase can be applied to living CPX transgenic embryos in ovo or in EASY culture either on a bead (asterisk, $\mathbf{G}, \mathbf{H}, \mathbf{I})$, or directly via pipetting or injection into the circulation (I) CFP not shown). In this way it is

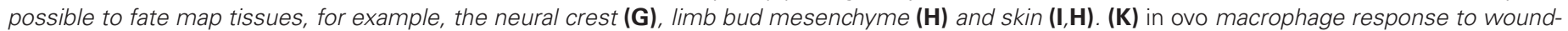
ing. Visualisation of embryonic macrophages with the CSF1R-eGFP transgene in HH31 embryonic limb buds $24 \mathrm{~h}$ after incisional wounding. Wounded limb bud right, control contralateral limb buds left. Asterisk indicates site of wounding. Compared with the contralateral control limb bud, there is no accumulation of macrophages at the wound site. (L) E14 embryo showing the neck region of the embryo where thymic lobes are visualised with the RUNX1-eGFPtransgene (arrows) due to eGFP expression in T-cell progenitors, whereas as the bulk of the embryo appears orange due to the combined expression of the RUNX1-eGFP (green) and CSF1R-mApple (red) in the abundant embryonic macrophage population that is found throughout the embryo. (M) RUNX1-Cre::CPX embryo yolk sac. Visualisation of dtTomato and eYFP positive haematopoietic cells in the yolk sac due to Cre-recombinase expression in the progenitors under a RUNX1-enhancer, thus allowing recombination at the lox sites within the Cytbow transgene and expression of fluorescent protein. (N) Visualisation of cell membrane dynamics during the closing optic fissure (between the asterisks) during eye development, via memGFP transgene. Figures care of RICE members. (A)Sang/NARF; (B,C,D,E,F,G,H,J) Davey/Sang; (I,K,L,M) Balic/Sang; (N) Rainger. 
Ros and colleagues have used GFP embryos in a number of incrementally sophisticated experiments: by grafting GFP+ZPA cells into non-GFP host limbs, they mapped the fate of the ZPA cells showing that, unlike in mice, the bird wing ZPA does not contribute to the wing digits (Towers et al., 2011). The conclusions from these studies were that the digits of the bird wing are probably digits 1 , 2 and 3 , suggesting that digits 4 and 5 were lost during evolution. Subsequently they used heterochronic GFP+ ZPA grafts to show that cells in the ZPA can 'count-time' during development in a retinoic-dependent fashion, which is thought to dictate when $\mathrm{SHH}$ expression is turned off (Chinnaiya et al., 2014) and also dictates proximal-distal regional HOX gene expression and cell adhesion changes (Saiz-Lopez et al., 2015, Saiz-Lopez et al., 2017). New transgenic lines, such as the Roslin Flamingo in which the red fluorescent protein TdTomato (TdT) is expressed ubiquitously, will add further to the technical opportunities to add insights into actions of the ZPA as an organiser, for example showing that some cellular components of the ZPA are highly migratory and contribute widely to the final limb (M. Davey unpublished, Fig. 2 A-E). The potential of grafting $\mathrm{TdT}^{+}$cells into $\mathrm{GFP}^{+}$recipient embryos (or vice versa) is considerable in order to facilitate more detailed donor cells tracking and live imaging.

In addition to increasing our understanding of previouslyidentified organisers, the Roslin Green GFP chicken has been used to test the existence of potential organisers. The ability to identify organisers, specialised regions of the embryo which impart pattern and communicate fate to surrounding embryonic tissues, has been through traditional 'cutting and pasting' grafting experiments for which the chicken is so amenable, the discovery of the ZPA limb organiser being a classic example (Saunders and Gasselling, 1968). Gene expression analyses, in silico and in vivo now give us the ability to predict new organisers, but the gold-standard test still holds true: can a presumptive organiser dictate fate to a naïve tissue? Through a bioinformatics analysis of transcriptome data from chicken embryos, it was predicted that the anterior intestinal portal (AIP) had an 'organiser-like' gene expression profile. Anderson et al., (2016) used the Roslin Green embryos in experiments recombining a GFP+ AIP with mesoderm that would not normally become heart tissue and showed that the AIP had organiser characteristics, inducing ventricular identity and suppressing atrial identity in this mesodermal population. These experiments added a valuable step in our understanding of heart induction, showing that induction of the heart by the endoderm is a multi-step process. Similar recombination experiments likewise have determined that the roof plate boundary is a contact dependent organiser of other tissues: the dorsal neural tube and the choroid plexus (Broom et al., 2012).

While the Roslin Greens have been used widely in fate mapping various tissues, for example the origin of the myocardium progenitors (Camp et al., 2012), GnRH-1 neurons (Sabado et al., 2012), the infundibulum (Pearson et al., 2011) as well as continued work on the fate of the neural crest (Barraud et al., 2010, Nagy et al., 2005), one of the more novel uses of the Roslin Greens has been in testing genotype-phenotype interactions in the embryo. This technique is common in Drosophila, through creation of genetically modified clones in fly embryos but it is otherwise not frequently used in vertebrates. By transplantation GFP+ to GFP- embryos' Zhao et al.,2010) were able to generate mix-sexed chimeras, with gonads consisting of female somatic cells in a male recipient embryo and vice versa. Analysis of these chimeric gonads showed that the somatic cells maintained the phenotype of the donor and were not affected by being in an opposite sex host. This result suggests that somatic sex identity is cell autonomous in chickens and not primarily influenced by the sex of the host bird. By recombining wildtype GFP+ limb tissue with limb buds from polydactylous (Po) chicken embryos Dunn et al.,2011) showed that the Po mutation was required in both the posterior and anterior limb bud tissue, unlike the conclusions from similar experiments in polydactylous mice. Even in vitro experiments, such as mixing wildtype fibroblasts with talpid ${ }^{3}$ mutant fibroblasts as previously carried out by researchers including Donald Ede (reviewed by Davey et al., this issue) have benefitted from the Roslin Greens, allowing cells from different genotypes to be mixed in the same culture leading to insights into the loss of cell polarity caused by the talpid ${ }^{3}$ mutation (Stephen et al., 2015).

\section{Transgenic chickens and understanding haematopoiesis}

While transgenics chickens which ubiquitously express proteins such as the Roslin Green have been widely utilised in varied and imaginative ways, targeted questions have also been addressed using specific chicken transgenic modifications. Murine models have enabled important discoveries on the developmental origins of haematopoietic cells; however, in utero development imposes critical limitations on the analysis of early development of haematopoietic cells. And while live imaging in zebrafish allows dynamic visualization of the formation of multi-potent progenitors/haematopoietic stem cells (HSC), as the main hematopoietic sites in zebrafish differ from those in higher vertebrates this model is also limited. The avian embryo is an excellent developmental model for haematopoietic cells development in higher vertebrates, due to its relatively large size and accessibility for experimental manipulations, with high rates of subsequent normal development. Early studies of chicken-quail chimeras have generated fundamental information on the early formation of haematopoietic cells (Dieterlen-Lievre, 1975, reviewed in Jaffredo, 2009), however these models do not allow visualisation of cell population of interest in the developing embryo. The development of transgenic technologies and possibility of live-imaging now makes the developing chicken embryo a particularly attractive model analysis of early events in vertebrate haematopoietic cells development.

Recently we reported the generation of the first transgenic chicken line ("MacReporter" chicken; Table 1) in which a reporter transgene is expressed in a specific haematopoietic cell lineage (Balic et al., 2014). Based upon control elements of the colony stimulating factor 1 receptor (CSF1R) locus, expression of the reporter gene provides a defined marker for macrophage-lineage cells (Fig. 2 $\mathrm{K}, \mathrm{L}$ ), identifying the earliest stages of macrophage development in the yolk sac, throughout embryonic development and in all adult tissues. The reporter genes permit detailed and dynamic visualisation of embryonic chicken macrophages. In embryonic zebrafish and Xenopus, macrophages are rapidly recruited to wound sites (Costa et al., 2008, Mathias et al., 2009), whereas this does not occur in mouse embryos until late in development (Hopkinson-Woolley et al., 1994). Using these MacReporter chicken embryos, we found that like early murine embryos, chicken embryonic macrophages are not recruited to incisional wounds, suggesting significant differences in embryonic macrophage function between fish/amphibian and amniote lineages (Balic et al., 2014). 
More recently we have developed a novel transgenic chicken line, based upon control elements of the Runt-related transcription factor 1 (RUNX1) locus which allows visualisation of chicken HSCs and haematopoietic cell progenitor populations (Fig. 2 L,M;A. Balic, manuscript in preparation). In combination with classic avian embryonic manipulation techniques, these RUNX1-reporter embryos allow the dynamic visualisation and precise origin of HSCs to be defined in the early embryo stage of an amniote vertebrate lineage.

\section{A forward look}

The transgenic technologies outlined above are now becoming routine and have the potential of bringing the chicken in line with the more commonly used transgenic models of the mouse, zebrafish, and rat. This is particularly useful as gene knock-out approaches and editing for more subtle genetic effects, such as manipulations and deletions of enhancers, are now possible. The chicken, will always have disadvantages compared to these model animals, largely due to the relatively long generation time and husbandry facilities required (rather less significant in the quail). The chicken does have significant advantages, including producing (naturally) pre-packaged and transportable embryos (fertilised eggs), which can be sent shipped to scientists to utilise in their experiments, bypassing the requirement for each laboratory to have access to their own poultry facility, as demonstrated by the wide uptake and use of Roslin Green embryos in the UK and in Europe (McGrew et al., 2008, Saiz-Lopez et al., 2017).

The unique strength of the chicken as a vertebrate model, has always been in anatomical approaches, for example in elucidating embryonic organisers through surgical grafting of embryonic tissues. The power of a new transgenic chicken technology combined with the traditional anatomical approaches in chicken potentially will bridge the gap between genetic and anatomy-driven research. The major challenge in vertebrate biology is to understand how organs consisting of many cells types co-ordinate a full anatomy during embryonic development and regeneration. How do different cell types respond differently in the same environment? How do subtle expression level differences and combinations of gene expression in neighbouring cells drive specific phenotypes? Modern transgenic chicken technology in the adult and embryo, combined with single cell transcriptomics has the potential to begin exploring these questions in unprecedented depth. For example, the Chameleon cytbow chicken will permit single cell fate mapping from small embryonic territories (Fig. 2 F-J; Saunders et al., manuscript in preparation).

Targeting the chicken embryo in ovowill allow the transient use of gene editing technology to produce tissue-specific alleles to perform spatiotemporal gene-function analyses without the associated cost of producing a line of birds carrying the desired mutations. Proofof-principle electroporations to target Pax7 (Véron et al., 2015) and DGCR8 (Dad Abu-Bonsrah et al., 2016) have been applied in studies within the developing chick neural tube but only weak phenotypes were observed with limited penetrance. Recent advances for editing in non-dividing cells (Suzuki et al., 2016) suggest that increased-efficiency routine targeting of various somatic tissues is now a distinct possibility, with the only theoretical limitation being the accessibility of the tissues during development. Transfection of cells in ovo has been generally limited by the transfection methods available, such as electroporation and the replication competent retroviral vector system RCAS. Transient CRISPR Cas9 editing in ovo currently depends on efficient transfection of both Cas9 expression vectors and vectors containing gRNAs, or combining these in large vectors. To improve efficiencies of genome editing, and exploit the opportunities of CRISPR technology a stable Cas9 expressing transgenic chicken line could be a valuable resource $A$ CAS9 mouse model was produced which stably expressed CAS9 in every cell of the animal allowing for the guide RNA to be delivered in trans (Platt et al., 2014).

As well as elucidating the role of genes important in development, these innovations could lead to high through-put screening in the chicken embryo for genes, single nucleotide polymorphisms and other QTL based genomic variants which influence production or immune function in the adult. Thus, as well as being an important model of embryogenesis, the chicken embryo could also be a cost-effective proof of principal step prior to the generation of specific transgenic lines.

As we have described here, technologies for all types of genome engineering are now available for the chicken, with the opportunities and impacts of applying CRISPR-based technologies only just beginning to be developed. We can increase the value of using the chicken embryo in answering basic questions in developmental biology, with directrelevance to understanding fundamental aspects of vertebrate development and also informing our understanding of aspects of the chicken that are important to the chicken as a food animal. The major limitation now to exploiting these technologies is the limited facilities available for housing experimental birds and the challenge of continuous maintenance of valuable, gene edited lines for experimental embryo provision.

\section{Acknowledgements}

$M D, A B, H S$ and $M M$ are supported by Institute Strategic Grant funding from the Biotechnology and Biological Sciences Research Council (BB/ J004316/1, BB/P013732/1), JR by Fellowship funding from Fight for Sight and The Roslin Foundation and MD by the British Society for Surgery of the Hand. Production of novel transgenic chicken lines has been supported by funding from the BBSRC BB/E011276/2, Wellcome Trust 094182/Z/10/Z and Medical Research Council MR/L018160/1. Forfurther information about the transgenic lines, contact Helen.Sang@Roslin.ed.ac.uk.

\section{References}

ANDERSON, C., KHAN, M.A., WONG, F., SOLOVIEVA, T., OLIVEIRA, N.M., BALDOCK, R.A., TICKLE, C., BURT, D.W. and STERN, C.D. (2016). A strategy to discover new organizers identifies a putative heart organizer. Nature Communications 7: 12656

BALIC, A., GARCIA-MORALES, C., VERVELDE, L., GILHOOLEY, H., SHERMAN A., GARCEAU, V., GUTOWSKA, M.W., BURT, D.W., KAISER, P., HUME, D.A. et al., (2014). Visualisation of chicken macrophages using transgenic reporter genes: insights into the development of the avian macrophage lineage. Development 141: 3255-3265

BARRAUD, P., SEFERIADIS, A.A., TYSON, L.D., ZWART, M.F., SZABO-ROGERS, H.L., RUHRBERG, C., LIU, K.J. and BAKER, C.V. (2010). Neural crest origin of olfactory ensheathing glia. Proc Natl Acad Sci USA 107: 21040-21045.

BOSSELMAN, R.A., HSU, R.Y., BOGGS, T., HU, S., BRUSZEWSKI, J., OU, S. KOZAR, L., MARTIN, F., GREEN, C., JACOBSEN, F. et al., (1989). Germline transmission of exogenous genes in the chicken. Science 243: 533-535.

BOWER, D.V., SATO, Y. and LANSFORD, R. (2011). Dynamic lineage analysis of embryonic morphogenesis using transgenic quail and 4D multispectral imaging. Genesis 49: 619-643.

BROOM, E.R., GILTHORPE, J.D., BUTTS, T., CAMPO-PAYSAA, F. and WINGATE, R.J. (2012). The roof plate boundary is a bi-directional organiser of dorsal neural 
tube and choroid plexus development. Development 139: 4261-4270.

CAMP, E., DIETRICH, S. and MUNSTERBERG, A. (2012). Fate mapping identifies the origin of SHF/AHF progenitors in the chick primitive streak. Plos One 7: e51948.

CHANG, I.K., YOSHIKI, A., KUSAKABE, M., TAJIMA, A., CHIKAMUNE, T., NAITO, M. and OHNO, T. (1995). Germ-Line Chimera Produced by Transfer of Cultured Chick Primordial Germ-Cells. Cell Biol. Int. 19: 569-576.

CHINNAIYA, K., TICKLE, C. and TOWERS, M. (2014). Sonic hedgehog-expressing cells in the developing limb measure time by an intrinsic cell cycle clock. Nature Comm. 5: 4230

CHOI, J.W., KIM, S., KIM, T.M., KIM, Y.M., SEO, H.W., PARK, T.S., JEONG, J.W., SONG, G. and HAN, J.Y. (2010). Basic Fibroblast Growth Factor Activates MEK/ ERK Cell Signaling Pathway and Stimulates the Proliferation of Chicken Primordial Germ Cells. Plos One 5: e12968.

CONG, L. and ZHANG, F. (2015). Genome Engineering Using CRISPR-Cas9 System. Methods Mol. Biol. 1239: 197-217.

COSTA, R.M., SOTO, X., CHEN, Y., ZORN, A.M. and AMAYA, E. (2008). spib is required for primitive myeloid development in Xenopus. Blood 112: 2287-2296.

DIETERLEN-LIEVRE, F. (1975). On the origin of haemopoietic stem cells in the avian embryo: an experimental approach. J Embryol Exp Morphol 33: 607-619.

DIMITROV, L., PEDERSEN, D., CHING, K.H., YI, H., COLLARINI, E.J., IZQUIERDO, S., VAN DE LAVOIR, M.C. and LEIGHTON, P.A. (2016). Germline Gene Editing in Chickens by Efficient CRISPR-Mediated Homologous Recombination in Primordial Germ Cells. Plos One 11: e0154303.

DUNN, I.C., PATON, I.R., CLELLAND, A.K., SEBASTIAN, S., JOHNSON, E.J., MCTEIR, L., WINDSOR, D., SHERMAN, A., SANG, H., BURT, D.W. et al., (2011). The chicken polydactyly (Po) locus causes allelic imbalance and ectopic expression of Shh during limb development. Dev Dyn 240: 1163-1172.

ETCHES, R.J., CLARK, M.E., TONER, A., LIU, G. and GIBBINS, A.M. (1996). Contributions to somatic and germline lineages of chicken blastodermal cells maintained in culture. Mol. Reprod. Dev. 45: 291-298.

EYAL-GILADI, H., GINSBURG, M. and FARBAROV, A. (1981). Avian primordial germ cells are of epiblastic origin. J Embryol Exp Morphol 65: 139-147.

HOPKINSON-WOOLLEY, J., HUGHES, D., GORDON, S. and MARTIN, P. (1994). Macrophage recruitment during limb development and wound healing in the embryonic and foetal mouse. J Cell Sci 107 (Pt 5): 1159-1167.

JAFFREDO, T. (2009). [The aortic endothelium in the embryo: genesis and role in hematopoiesis]. J Soc Biol 203: 155-160.

KALINA, J., SENIGL, F., MICAKOVA, A., MUCKSOVA, J., BLAZKOVA, J., YAN, H., POPLSTEIN, M., HEJNAR, J. and TREFIL, P. (2007). Retrovirus-mediated in vitro gene transfer into chicken male germ line cells. Reproduction 134: 445-453.

KIM, J.N., PARK, T.S., PARK, S.H., PARK, K.J., KIM, T.M., LEE, S.K., LIM, J.M. and HAN, J.Y. (2010). Migration and proliferation of intact and genetically modified primordial germ cells and the generation of a transgenic chicken. Biol Reprod 82: $257-262$.

LE DOUARIN, N.M. and DIETERLEN-LIEVRE, F. (2013). How studies on the avian embryo have opened new avenues in the understanding of development: A view about the neural and hematopoietic systems. Dev. Growth Diff. 55: 1-14.

LILLICO, S.G., MCGREW, M.J., SHERMAN, A. and SANG, H.M. (2005). Transgenic chickens as bioreactors for protein-based drugs. Drug Discov Today 10: 191-196.

LOVE, J., GRIBBIN, C., MATHER, C. and SANG, H. (1994). Transgenic birds by DNA microinjection. Biotechnology (N Y) 12: 60-63.

MACDONALD, J., GLOVER, J.D., TAYLOR, L., SANG, H.M. and MCGREW, M.J. (2010). Characterisation and Germline Transmission of Cultured Avian Primordial Germ Cells. Plos One 5.

MACDONALD, J., TAYLOR, L., SANG, H.M. and MCGREW, M.J. (2012). Genetic Modification of the chicken genome using transposable elements. Transgenic Res. 21: 912-913.

MATHIAS, J.R., DODD, M.E., WALTERS, K.B., YOO, S.K., RANHEIM, E.A. and HUTTENLOCHER, A. (2009). Characterization of zebrafish larval inflammatory macrophages. Dev Comp Immunol 33: 1212-1217.

MCGREW, M.J., SHERMAN, A., ELLARD, F.M., LILLICO, S.G., GILHOOLEY, H.J., KINGSMAN, A.J., MITROPHANOUS, K.A. and SANG, H. (2004). Efficient production of germline transgenic chickens using lentiviral vectors. Embo Reports 5: $728-733$
MCGREW, M.J., SHERMAN, A., LILLICO, S.G., ELLARD, F.M., RADCLIFFE, P.A., GILHOOLEY, H.J., MITROPHANOUS, K.A., CAMBRAY, N., WILSON, V. and SANG, H. (2008). Localised axial progenitor cell populations in the avian tail bud are not committed to a posterior Hox identity. Development 135: 2289-2299.

NAGY, N., BIRO, E., TAKACS, A., POLOS, M., MAGYAR, A. and OLAH, I. (2005). Peripheral blood fibrocytes contribute to the formation of the avian spleen. Dev. Dynam. 232: 55-66.

NIEUWKOOP, P.D. and SUTASURYA, L.A. (1979). Primordal Germ Cells in the Chordates. Cambridge University Press, Cambridge.

OISHI, I., YOSHII, K., MIYAHARA, D., KAGAMI, H. and TAGAMI, T. (2016). Targeted mutagenesis in chicken using CRISPR/Cas9 system. Scientific Reports 6: 23980

PAIN, B., CLARK, M.E., SHEN, M., NAKAZAWA, H., SAKURAI, M., SAMARUT, J. and ETCHES, R.J. (1996). Long-term in vitro culture and characterisation of avian embryonic stem cells with multiple morphogenetic potentialities. Development 122: 2339-2348.

PARK, T.S. and HAN, J.Y. (2012). piggyBac transposition into primordial germ cells is an efficient tool for transgenesis in chickens. Proc NatIAcad SciUSA 109: 9337-9341.

PARK, T.S., LEE, H.J., KIM, K.H., KIM, J.S. and HAN, J.Y. (2014). Targeted gene knockout in chickens mediated by TALENs. Proc Natl Acad Sci USA 111: 12716-12721.

PEARSON, C.A., OHYAMA, K., MANNING, L., AGHAMOHAMMADZADEH, S. SANG, H. and PLACZEK, M. (2011). FGF-dependent midline-derived progenitor cells in hypothalamic infundibular development. Development 138: 2613-2624.

PETITTE, J.N., CLARK, M.E., LIU, G., VERRINDER GIBBINS, A.M. and ETCHES, R.J. (1990). Production of somatic and germline chimeras in the chicken by transfer of early blastodermal cells. Development 108: 185-189.

PLATT, R.J., CHEN, S., ZHOU, Y., YIM, M.J., SWIECH, L., KEMPTON, H.R., DAHLMAN, J.E., PARNAS, O., EISENHAURE, T.M., JOVANOVIC, M. et al., (2014). CRISPR Cas9 knockin mice for genome editing and cancer modeling. Cell 159: 440-455.

SABADO, V., BARRAUD, P., BAKER, C.V.H. and STREIT, A. (2012). Specification of $\mathrm{GnRH}-1$ neurons by antagonistic FGF and retinoic acid signaling. Dev. Biol. 362: 254-262.

SAIZ-LOPEZ, P., CHINNAIYA, K., TOWERS, M. and ROS, M.A. (2017). Intrinsic properties of limb bud cells can be differentially reset. Development 144: 479-486.

SANG, H. (2004). What is the value of another method for making transgenic animals? Transgenic Res. 13: 511-512.

SAUNDERS, J.W. and GASSELLING, M.T. (1968). Ectodermal-mesenchymal interactions in the origin of limb symmetry. In Mesenchymal-epithelial Interactions, (ed. FLEISCHMEYER, B.), pp.78-97

SCOTT, B.B. and LOIS, C. (2005). Generation of tissue-specific transgenic birds with lentiviral vectors. Proc Natl Acad Sci USA 102: 16443-16447.

STEPHEN, L.A., TAWAMIE, H., DAVIS, G.M., TEBBE, L., NURNBERG, P., NURNBERG, G., THIELE, H., THOENES, M., BOLTSHAUSER, E., UEBE, S. et al., (2015). TALPID3 controls centrosome and cell polarity and the human ortholog KIAA0586 is mutated in Joubert syndrome (JBTS23). Elife 4: e08077.

TAYLOR, L., CARLSON, D.F., NANDI, S., SHERMAN, A., FAHRENKRUG, S.C. and MCGREW, M.J. (2017). Efficient TALEN-mediated gene targeting of chicken primordial germ cells. Development 144: 928-934.

TOWERS, M., SIGNOLET, J., SHERMAN, A., SANG, H. and TICKLE, C. (2011) Insights into bird wing evolution and digit specification from polarizing region fate maps. Nature Comm. 2: 246.

TSUNEKAWA, N., NAITO, M., SAKAI, Y., NISHIDA, T. and NOCE, T. (2000). Isolation of chicken vasa homolog gene and tracing the origin of primordial germ cells. Development 127: 2741-2750.

TYACK, S.G., JENKINS, K.A., O'NEIL, T.E., WISE, T.G., MORRIS, K.R., BRUCE, M.P., MCLEOD, S., WADE, A.J., MCKAY, J., MOORE, R.J. et al., (2013). A new method for producing transgenic birds via direct in vivo transfection of primordial germ cells. Transgenic Res 22: 1257-1264.

VAN DE LAVOIR, M.C., DIAMOND, J.H., LEIGHTON, P.A., MATHER-LOVE, C., HEYER, B.S., BRADSHAW, R., KERCHNER, A., HOOI, L.T., GESSARO, T.M. SWANBERG, S.E. et al., (2006a). Germline transmission of genetically modified primordial germ cells. Nature 441: 766-769.

VAN DE LAVOIR, M.C., MATHER-LOVE, C., LEIGHTON, P., DIAMOND, J.H., HEYER, B.S., ROBERTS, R., ZHU, L., WINTERS-DIGIACINTO, P., KERCHNER, A., GES SARO, T. et al., (2006b). High-grade transgenic somatic chimeras from chicken embryonic stem cells. Mech Dev 123: 31-41. 


\section{M.G. Davey et al.}

VICK, L., LI, Y. and SIMKISS, K. (1993). Transgenic birds from transformed primordial germ cells. Proc Biol Sci 251: 179-182.

WHYTE, J., GLOVER, J.D., WOODCOCK, M., BRZESZCZYNSKA, J., TAYLOR, L., SHERMAN, A., KAISER, P. and MCGREW, M.J. (2015). FGF, Insulin, and
SMAD Signaling Cooperate for Avian Primordial Germ Cell Self-Renewal. Stem cell Reports 5: 1171-1182.

ZHAO, D., MCBRIDE, D., NANDI, S., MCQUEEN, H.A., MCGREW, M.J., HOCKING, P.M., LEWIS, P.D., SANG, H.M. and CLINTON, M. (2010). Somatic sex identity is cell autonomous in the chicken. Nature 464: $237-242$. 


\section{Further Related Reading, published previously in the Int. J. Dev. Biol.}

Directed genome engineering for genome optimization

Kathleen D'Halluin and Rene Ruiter

Int. J. Dev. Biol. (2013) 57: 621-627

https://doi.org/10.1387/ijdb.130217kd

Natural and artificial routes to pluripotency

Winfried H. Krueger, Lindsey C. Swanson, Borko Tanasijevic and Theodore P. Rasmussen

Int. J. Dev. Biol. (2010) 54: 1545-1564

https://doi.org/10.1387/ijdb.103199wk

\section{Animal reproduction biotechnology in Poland}

Zdzislaw Smorag, Lucyna Katska-Ksiazkiewicz, Maria Skrzyszowska, Jacek Jura, Barbara Gajda and Michal Bochenek Int. J. Dev. Biol. (2008) 52: 151-155

https://doi.org/10.1387/ijdb.072325zs

Cellular dynamics and molecular control of the development of organizer-derived cells in quail-chick chimeras Jean-Baptiste Charrier, Martin Catala, Françoise Lapointe, Nicole Le Douarin and Marie-Aimée Teillet

Int. J. Dev. Biol. (2005) 49: 181-191

http://www.intjdevbiol.com/web/paper/041962jc

Thirteen years of manipulating the mouse genome: a personal history

A Bradley, B Zheng and P Liu

Int. J. Dev. Biol. (1998) 42: 943-950

http://www.intjdevbiol.com/web/paper/9853825

Transplantations of the chick eye anlage reveal an early determination of nasotemporal polarity

D Dütting and S U Meyer

Int. J. Dev. Biol. (1995) 39: 921-931

http://www.intjdevbiol.com/web/paper/8901194

Embryo culture, stem cells and experimental modification of the embryonic genome. An interview with Professor Ralph Brinster.

Juan Aréchaga

Int. J. Dev. Biol. (1998) 42: 861-878

http://www.intjdevbiol.com/web/paper/9853816

5 yr ISI Impact Factor $(2016)=2.421$

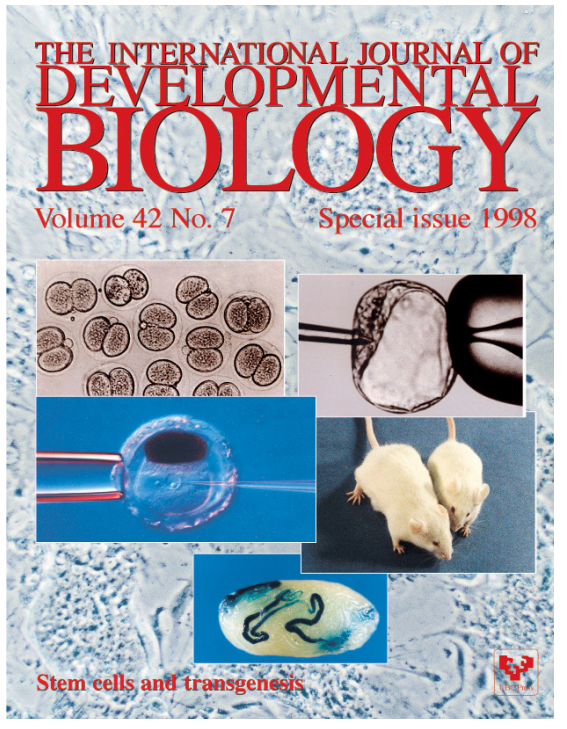

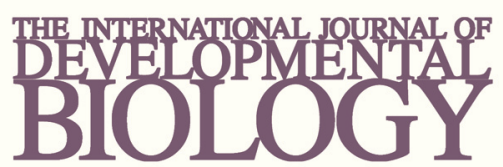

Volume 54 Nos. 6/7
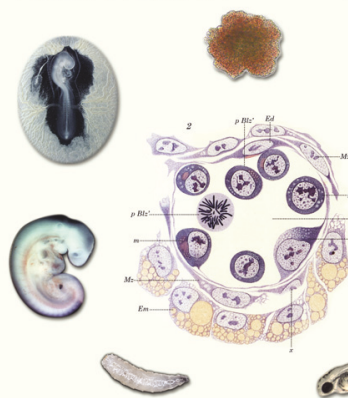

Developmental Hematopoiesis
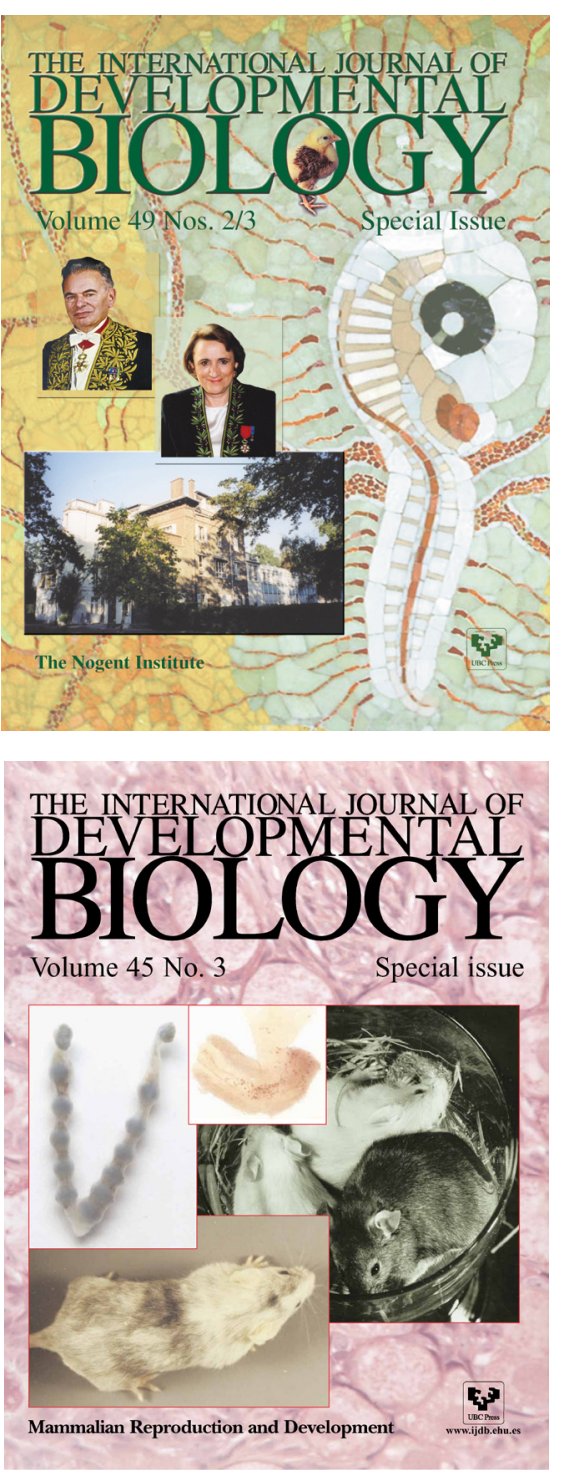